\title{
THE FIRST 6TH-MONTH NUTRITIONAL STATUS OF A FULL-TERM CHILD IN EXCLUSIVE BREASTFEEDING: A LITERATURE REVIEW
}

\author{
Relisa Nuris Shifa ${ }^{1}$, Sulistiawati ${ }^{2}$, Endyka Erye Frety ${ }^{3}$, Astika Gita Ningrum ${ }^{4}$ \\ ${ }^{1}$ Bachelor program of Midwifery, Faculty of Medicine, Universitas Airlangga, Surabaya, 60131, Indonesia \\ ${ }^{2}$ Lecturer in Depatement of Public Health Science, Faculty of Medicine Universitas Airlangga, Indonesia \\ ${ }^{3,4}$ Lecturer in Midwifery Program, Faculty of Medicine, Universitas Airlangga, Surabaya, Indonesia
}

\section{INFORMASI ARTIKEL:}

\author{
Riwayat Artikel: \\ Tanggal diterima: Maret 2021 \\ Tanggal di revisi: Maret 2021 \\ Tanggal di Publikasi: April 2021 \\ Key Word : nutritional \\ status, anthropometry, exclusive \\ breastfeeding, exclusive human milk, \\ exclusive breast milk, infants, 0-6 months
}

\section{A B S T R A C T}

Background: The first six months after birth are part of the first 1000 days, a golden period for child development. In this period, the child needed proper nutrition to support optimal development and as nutrition programming. WHO recommends exclusive breastfeeding (EBF) for the first 6th-month. Adequacy of nutrition and optimal growth can be assessed using the nutritional status.

Aim: This study analyzes the relationship between EBF for the first 6 months with the nutritional status of a full-term infant aged 0-6 months. The nutritional status assessed using anthropometric measurements and child growth standards.

Methods: This type of literature review research uses the PRISMA, PICO, and Boolean Operator methods. The research question with PICO standard "What is a relationship between exclusive breastfeeding practice and nutritional status of children aged 0-6 months?". Relevant literature was obtained from 8 databases: Scopus, Portal Garuda, Proquest, Mendeley, Pubmed, Oxford, Science Direct, and Sage. Literature was limited to the last 10 years. There are 6 relevant pieces of literature included for review. The literature quality assessment uses a quantitative study quality assessment tool released by the EPHPP (Effective Public Health Practice Project) and produces 5 pieces of literature worthy of review.

Results: From 5 kinds of literature, there were various indicators of nutritional status such as weight-for-age (WAZ), length-for-age (LAZ), weight-for-length (WLZ), Body Mass Index (BMI)-for-age, and head circumference (HC)-for-age. The results were dominated by insignificant results, except the HC-for-age indicator stated that there were significant results. The author explores the causes of insignificant results. Explores based on the indicators that include in studies, the information based on studies, and the possible consequences that adjusted to the data based on the studies. The Author found that the mother plays an important role in the production and provision of breast milk. The quality of breastmilk depends on the mother, also how she gives it to their infant. It has to be based on the WHO recommendation.

Conclusion: The result of these studies affirms that EBF didn't significantly affect the indicators of WAZ, LAZ, WLZ, and BMI-for-age, but significantly affected the head circumference-for-age indicator. 


\section{INTRODUCTION}

The first 1,000 days of life are childhood from conception to 24 months of age, a critical period for growth and development, especially for the brain (1000 days, 2020). Children's basic needs must be fulfilled for optimal growth and development. One of the basic need for childhood is nutrition (Soetjiningsih \& Ranuh, 2013). In the first six months, children needed a high demand for nutrition (Watson, et. al., 2013). In the first year of life after birth, the child's digestive tract is still immature, so the right type of food is needed (Basrowi, 2018). With the right food, a child

can adapt to the conditions of their digestive tract and can meet the nutritional needs at that age.

Breast-milk is a liquid secreted from the mammary glands that can meet nutritional and non-nutritional needs. Breast-milk can support the development, growth, and health of the baby. The nutritional components of breast milk contain carbohydrates, proteins, and fats. The non-nutritional components include antimicrobial factors, immune factors, trophic factors, growth modulators, hormonal, digestive enzymes, and commensal bacteria. The composition of breast milk is dynamic and varies, depending on the age of the baby (colostrum, transitional breastfeeding, Mature breastfeeding), time of breastfeeding (Foremilk, Hindmilk), gestational age of the baby (Preterm milk and Term milk), maternal factors (lifestyle, dietary variation, interpopulation mother, nutritional status, parity), environment, diurnal, and management of breast milk (storage and pasteurization) (Bachour, Yafawi, Jaber, Choueiri, \& AbdelRazzak, 2012; Badillo-Suárez, RodríguezCruz, \& Nieves-Morales, 2017; Ballard \& Morrow, 2013; Prawirohardjo, 2016; Skirgaudas, 1987). There are 4 patterns of breastfeeding. Exclusive breastfeeding (EBF) is one of them. EBF is a method of breastfeeding only, without other types of food or drink, but allows receiving ORS, drops, and syrups (vitamins, minerals, and drugs) (WHO, 2001).

The World Health Organization (WHO) recommends EBF along the first 6 months of life after birth, with a target by 2030 reaching $75 \%$ worldwide. The latest data by UNICEF in 2019, the average coverage of exclusive breastfeeding in the first 6 months was $44 \%$. On each continent, the latest data on EBF shows that Asia is $42.3 \%$, Africa is $43.4 \%$, and the united state of America is $34.7 \%$. According to data from the global nutrition report, Europe and Australia don't show data (Global Nutrition Report, 2019; UNICEF, 2019; WHO \& UNICEF, 2019).

Nutritional status is an individual physiological condition resulting from the relationship between nutritional intake, needs, and the body's ability to digest, absorb, and use these nutrients. If there is an excess or lack of nutrition in individual needs, the condition is called malnutrition.

Malnutrition during the first 1000 days is a critical condition, will be difficult to change, and has an impact on the quality of life. Malnutrition can be identified by assessing nutritional status through anthropometric measurements and put into child growth standards. Data of malnutrition incidence in children below 5 years show that there is wasting of $6.9 \%, 21.3 \%$ stunting, $5.6 \%$ overweight, and underweight there's only data from each country. Malnutrition data in each continent as follows, Asia (wasting 9.4\%, stunting $22.7 \%$, overweight $5.2 \%$ ), Africa (wasting 7.1\%, stunting 30\%, overweight 4.9 ), United State of America (wasting 0.4\%, Stunting 3.5\%, overweight 9.4\%), Australia (wasting 0\%, Stunting 2\%, overweight 7.7\%), Europe (no data) (Global Nutrition Report, 2019; UNICEF, 2019; WHO \& UNICEF, 2019).

In this study, we present a literature review of the nutritional status term children aged 0-24 months with EBF for the first 6 months after birth..

\footnotetext{
"Korespondensi: relisa.nuris.ifa-2016@fk.unair.ac.id
} 


\section{METHOD}

\section{Selection of studies}

We used literature published for the last 10 years. The literature was reselected using inclusion and exclusion criteria. The flow diagram of the literature search and selection process is depicted in Figure 1. The search strategy identified 3,146 publications, and we do the abstract screening. There are 118 fulltext articles reviewed to assess eligibility. 112 studies were excluded after full-text review for the following reasons: duplicate article (9), non-research study (2), interventional, qualitative, and systematic reviews study (9), studies with preterm birth and unknown birth (86), irrelevant (5), inconsistent (1).

\section{Characteristic of studies included}

There are five studies were included in assessed the quality of study in TABLE 1 . Assessment result shows that there are one studies were categorized as a strong rating, four studies were categorized as a moderate rating, and one study was categorized as a weak rating. According to this quality assessment, we include five studies without weak study. The title $\&$ author of the article, description of the source of the article, the background of the research site, research method, and outcomes were identified and summarized in TABLE 2. The five studies consist of 3.237 participants. One article is a randomized controlled trial (RCT), three articles were cross-sectional studies, and one other article is a prospective study. From 5 articles that were reviewed, the study area was carried out on three continents and five countries. One study in Europe (Iceland), two studies in Asia (China and Indonesia), and two studies in Africa (North Africa and West Africa 
The Southeast Asian Journal of Midwifery Vol.7, No.1, April 2021, p: 1-21

E-ISSN: 2476-972X

P-ISSN: 2476-9738

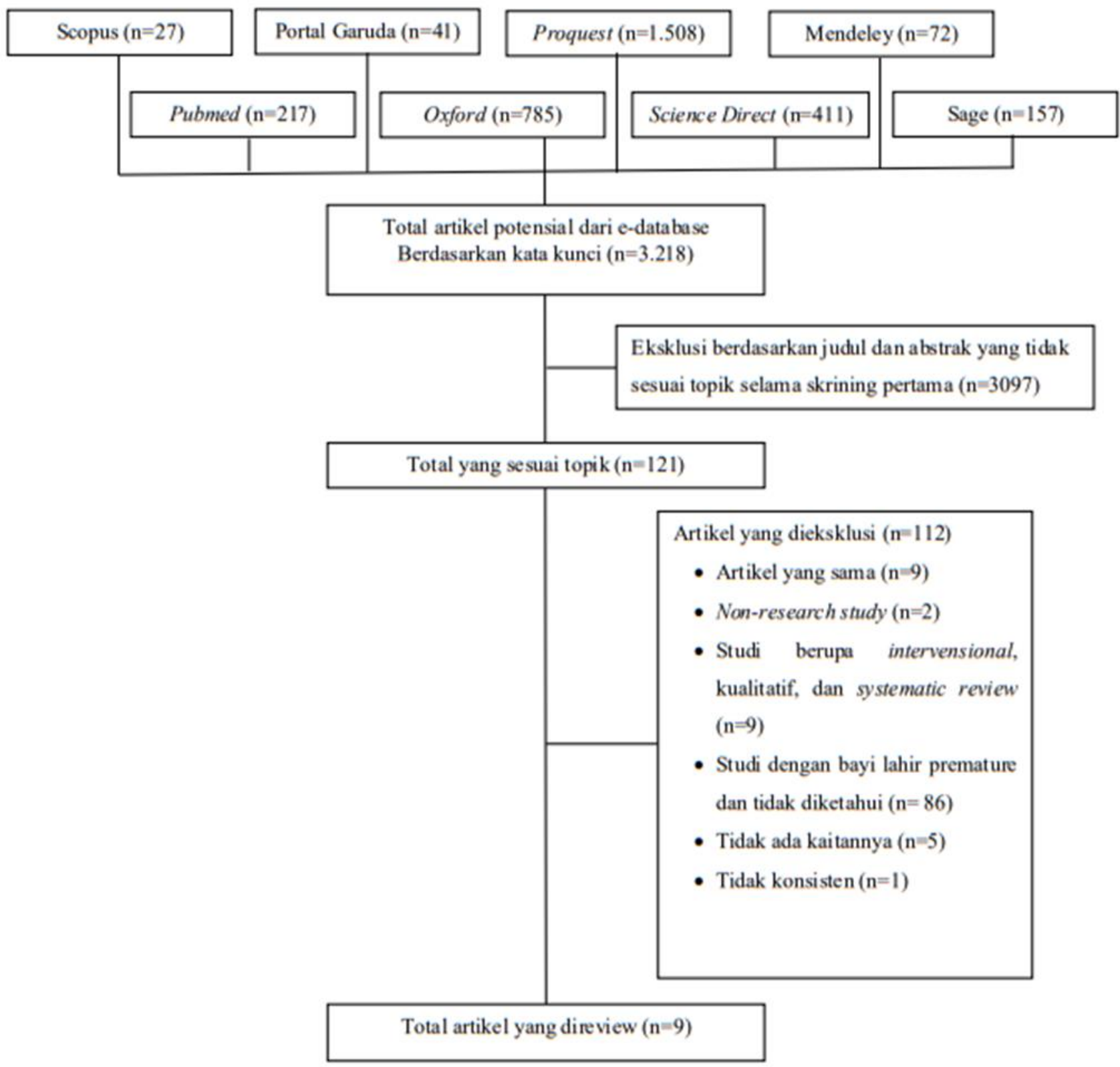

FIGURE 1. Flowchart of the search strategy used in this review set put according PRISMA 
The Southeast Asian Journal of Midwifery Vol.7, No.1, April 2021, p: 1-21

TABLE 1. Quality ratings of studies

\begin{tabular}{|l|c|c|c|c|c|c|c|}
\hline \multicolumn{1}{|c|}{ Author } & $\begin{array}{c}\text { Selecti } \\
\text { on } \\
\text { bias }\end{array}$ & $\begin{array}{c}\text { Study } \\
\text { design }\end{array}$ & $\begin{array}{c}\text { Confound } \\
\text { ers }\end{array}$ & $\begin{array}{c}\text { Blindi } \\
\text { ng }\end{array}$ & $\begin{array}{c}\text { Data } \\
\text { collection } \\
\text { method }\end{array}$ & $\begin{array}{c}\text { Withdra } \\
\text { wals and } \\
\text { dropouts }\end{array}$ & Rating \\
\hline $\begin{array}{l}\text { (Anindya et al., } \\
\text { 2019) }\end{array}$ & 1 & 3 & 1 & 2 & 1 & 1 & moderate \\
\hline $\begin{array}{l}\text { (Bechiri et al., } \\
\text { 2020) }\end{array}$ & 2 & 3 & 1 & 2 & 1 & 1 & moderate \\
\hline $\begin{array}{l}\text { (Ma et al., } \\
\text { 2014) }\end{array}$ & 1 & 3 & 1 & 2 & 1 & 1 & moderate \\
\hline $\begin{array}{l}\text { (Tobi \& } \\
\text { George, 2019) }\end{array}$ & 1 & 3 & 1 & 2 & 1 & 1 & moderate \\
\hline $\begin{array}{l}\text { (Wells et al., } \\
\text { 2012) }\end{array}$ & 1 & 1 & 1 & 2 & 1 & 1 & Strong \\
\hline
\end{tabular}

TABLE 2. Summary of the study

\begin{tabular}{|c|c|c|c|c|c|c|}
\hline No. & $\begin{array}{l}\text { Article } \\
\text { title, } \\
\text { author }\end{array}$ & $\begin{array}{c}\text { Database, } \\
\text { journal, } \\
\text { year, } \\
\text { edition, } \\
\text { volume, } \\
\text { numbers, }\end{array}$ & $\begin{array}{c}\text { The } \\
\text { research } \\
\text { location }\end{array}$ & $\begin{array}{c}\text { Research } \\
\text { methods } \\
\text { (study design, } \\
\text { samples, variables, } \\
\text { instruments, analysis) }\end{array}$ & $\begin{array}{l}\text { Results } \\
\text { Analysis }\end{array}$ & $\begin{array}{l}\text { Summary of } \\
\text { research } \\
\text { results }\end{array}$ \\
\hline 1. & $\begin{array}{l}\text { Hubunga } \\
n \\
\text { pemberia } \\
n \text { ASI } \\
\text { eksklusif } \\
\text { dan } \\
\text { status } \\
\text { gizi ibu } \\
\text { dengan } \\
\text { pertumb } \\
\text { uhan } \\
\text { lingkar } \\
\text { kepala } \\
\text { bayi usia } \\
6 \text { bulan } \\
\text { (Anindya } \\
\text { et al., } \\
\text { 2019) }\end{array}$ & $\begin{array}{c}\text { Mendeley,A } \\
\text { merta } \\
\text { Nutrition, } \\
2019 \text {, } \\
3,4.263\end{array}$ & $\begin{array}{c}\text { Asia, } \\
\text { Indonesi } \\
\text { a, East } \\
\text { Java, } \\
\text { Jember, } \\
\text { Kaliwate } \\
\text { s }\end{array}$ & $\begin{array}{l}\text { D: } \\
\text { Cross-sectional study } \\
\text { S: } \\
128 \text { babies aged } 6 \\
\text { months in Kaliwates, } \\
\text { Jember, East Java } \\
\text { V: } \\
\text { Independent } \\
\text { Exclusive breastfeeding } \\
\text { for } 6 \text { months } \\
\text { Dependent } \\
\text { Growth and nutritional } \\
\text { status of children aged } \\
6 \text { months } \\
\text { I: } \\
\text { Data } \\
\text { Breastfeeding history: } \\
\text { questions and answers } \\
\text { \& KMS data } \\
\text { Anthropometric } \\
\text { Measurements } \\
\text { HC: measuring head } \\
\text { circumference in } \\
\text { cm }\end{array}$ & $\begin{array}{l}\text { There were } 91 \\
(71.1 \%) \text { of the } \\
128 \text { samples } \\
\text { were given } \\
\text { EBF. The } \\
\text { results of } \\
\text { nutritional } \\
\text { status with the } \\
\text { HC-for-age } \\
\text { indicator } \\
\text { showed that } \\
\text { there were } 98 \\
\text { (76.6\%) } \\
\text { samples that } \\
\text { had normal } \\
\text { values (-2 to } \\
\text { until + 2SD) } \\
\text { and } 30 \\
(23.4 \%) \\
\text { samples had } \\
\text { microcephaly } \\
\text { results (<- } \\
\text { 2SD). The } \\
\text { results that } \\
\text { showed the } \\
\text { there was a } \\
\text { significant }\end{array}$ & $\begin{array}{l}\text { There was a } \\
\text { significant } \\
\text { result between } \\
\text { nutritional } \\
\text { status and HC- } \\
\text { for-age } \\
\text { indicators with } \\
\text { EBF in the first } \\
\text { 6th-months. }\end{array}$ \\
\hline
\end{tabular}




\begin{tabular}{|c|c|c|c|c|c|c|}
\hline & & & & $\begin{array}{l}\text { Assessment of } \\
\text { Nutritional Status } \\
\text { WHO child growth } \\
\quad \text { standard, z-score } \\
\text { A: } \\
\text { The tools used in the } \\
\quad \text { analysis } \\
\text { SPSS } \\
\text { The method used for } \\
\text { statistical analysis } \\
\text { tests } \\
\text { - Chi-square }\end{array}$ & $\begin{array}{l}\text { relationship } \\
\text { between } \\
\text { exclusive } \\
\text { breastfeeding } \\
\text { and the } \\
\text { growth of the } \\
\text { HC-for-age (p } \\
<0.001) \text {. }\end{array}$ & \\
\hline $\begin{array}{c}\mathrm{Nu} \\
\mathrm{t}\end{array}$ & $\begin{array}{l}\text { Breastfee } \\
\text { ding and } \\
\text { growth } \\
\text { of } \\
\text { healthy } \\
\text { infants } \\
\text { followed } \\
\text { from } \\
\text { birth to } \\
18 \\
\text { months } \\
\text { (Bechiri } \\
\text { et al., } \\
2020)\end{array}$ & $\begin{array}{c}\text { Scopus, } \\
\text { African } \\
\text { Journal of } \\
\text { food, } \\
\text { agriculture, } \\
\text { nutrition, } \\
\text { and } \\
\text { developmen } \\
\text { t, 20, 5, } \\
16386- \\
16402\end{array}$ & $\begin{array}{c}\text { Afrika. } \\
\text { Afrika } \\
\text { Utara, } \\
\text { Algeria }\end{array}$ & $\begin{array}{l}\text { D: } \\
\text { Prospective Study } \\
\text { S: } \\
159 \text { bayi usia 0-18 } \\
\text { bulan di Algeria bagian } \\
\text { north east } \\
\text { V: } \\
\text { Independen } \\
\text { Exclusive breastfeeding } \\
\text { for<6 months } \\
\text { Dependen } \\
\text { Nutirional status of } \\
\text { children 0-18 months } \\
\text { I: - } \\
\text { Data } \\
\text { - } \\
\text { B, PB, LK lahir : } \\
\text { Data Riwayat } \\
\text { Kesehatan } \\
\text { Anthropometric } \\
\text { Measurements } \\
\text { - } \\
\text { eight: SECA baby } \\
\text { weighing } \\
\text { (accuracy 100 g) } \\
\text { ength: horizontal } \\
\text { board (accuration } 1 \\
\text { mm) } \\
\text { C: } \\
\text { flexible measuring } \\
\text { tape (accuracy } 1 \text { mm) } \\
\text { Assessment } \\
\text { Nutritional Status }\end{array}$ & $\begin{array}{l}\text { There were } 25 \\
(15.7 \%) \\
\text { samples that } \\
\text { were EBF in } \\
\text { the 1st-month. } \\
\text { The number of } \\
\text { samples was } \\
\text { EBF decreased } \\
\text { to } 12 \text { (7.5\%) } \\
\text { by the 5th- } \\
\text { month. } \\
\text { Nutrition } \\
\text { status data not } \\
\text { according to } \\
\text { the type of } \\
\text { feeding, but } \\
\text { directly } \\
\text { becomes one } \\
\text { data. There's a } \\
\text { statement } \\
\text { indicating that } \\
\text { in the first 5th- } \\
\text { month there's } \\
82.8 \% \text { of } \\
\text { babies have } \\
\text { normal } \\
\text { categories on } \\
\text { indicators } \\
\text { WAZ, LAZ, } \\
\text { and BMI-for } \\
\text { age. 7.1\% are } \\
\text { wasting, 4.8\% } \\
\text { are lean, and } \\
3.1 \% \text { are } \\
\text { overweight in } \\
\text { age } 4 \text { months. } \\
\text { Result show } \\
\text { an }\end{array}$ & $\begin{array}{c}\text { There was an } \\
\text { insignificant } \\
\text { difference } \\
\text { between the } \\
\text { type of } \\
\text { breastfeeding } \\
\text { and nutritional } \\
\text { status. }\end{array}$ \\
\hline
\end{tabular}




\begin{tabular}{|c|c|c|c|c|c|c|}
\hline & & & & $\begin{array}{l}\text { WHO Child Growth } \\
\text { Standard, Z-Score } \\
\text { A: } \\
\text { The tools used in the } \\
\text { analysis } \\
\text { - Excel } \\
\text { Spreadsheet } \\
\text { - R [22] version } 3.4 .1 \\
\text { - Anthro software } \\
\text { version } 3.2 .2 \\
\text { The method used for } \\
\text { statistical analysis } \\
\text { tests } \\
\text { - Chi-2 } \\
\text { - Student } \\
\text { - Fisher }\end{array}$ & $\begin{array}{l}\text { insignificant } \\
\text { difference } \\
\text { between sexes } \\
(p>0.05)\end{array}$ & \\
\hline 3. & $\begin{array}{l}\text { Nutrition } \\
\text { al status } \\
\text { of } \\
\text { breast- } \\
\text { fed and } \\
\text { non- } \\
\text { exclusive } \\
\text { ly breast- } \\
\text { fed } \\
\text { infants } \\
\text { from } \\
\text { birth to } \\
\text { age } 5 \\
\text { months } \\
\text { in } 8 \\
\text { Chinese } \\
\text { cities } \\
\text { (Ma et } \\
\text { al., } \\
\text { 2014) }\end{array}$ & $\begin{array}{c}\text { Proquest, } \\
\text { Asia Pacific } \\
\text { Journal of } \\
\text { Clinical } \\
\text { Nutrition, } \\
2014,23 \text {, } \\
2,282-292\end{array}$ & $\begin{array}{l}\text { Asia, } \\
\text { China }\end{array}$ & $\begin{array}{l}\text { D: } \\
\text { Cross-sectional study } \\
\text { S: } \\
1078 \text { (divided into } 2 \\
\text { groups, namely } 0-2 \\
\text { months (622) \& } 3-5 \\
\text { months (456)) in } 8 \\
\text { urban cities as a result } \\
\text { of a nutrition survey at } \\
\text { the care service center } \\
\text { in each city } \\
\text { V: } \\
\text { Independent } \\
\text { EBF for the first } 6 \\
\text { months after birth } \\
\text { Dependent } \\
\text { The nutritional status of } \\
\text { children who are EBF } \\
\text { for the first } 6 \text { months } \\
\text { after birth with } \\
\text { indicators of WAZ, } \\
\text { LAZ, WLZ. } \\
\text { I: } \\
\text { Anthropometric } \\
\text { Lenght: measurements } \\
\text { board mearing } \\
\text { Weight: } \\
\text { pediatric scale } \\
\text { Assessment } \\
\text { Nutritional Status } \\
\text { Not }\end{array}$ & 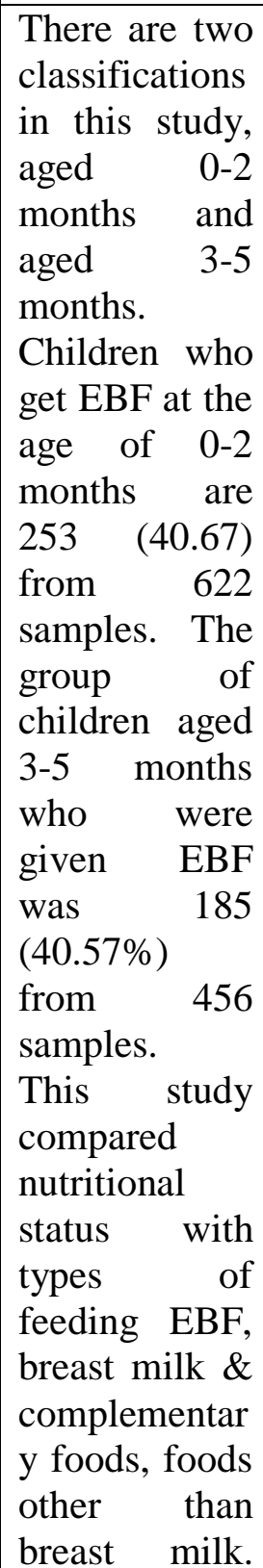 & $\begin{array}{c}\text { There was an } \\
\text { insignificant } \\
\text { difference } \\
\text { between the } \\
\text { type of } \\
\text { breastfeeding } \\
\text { and nutritional } \\
\text { status. }\end{array}$ \\
\hline
\end{tabular}




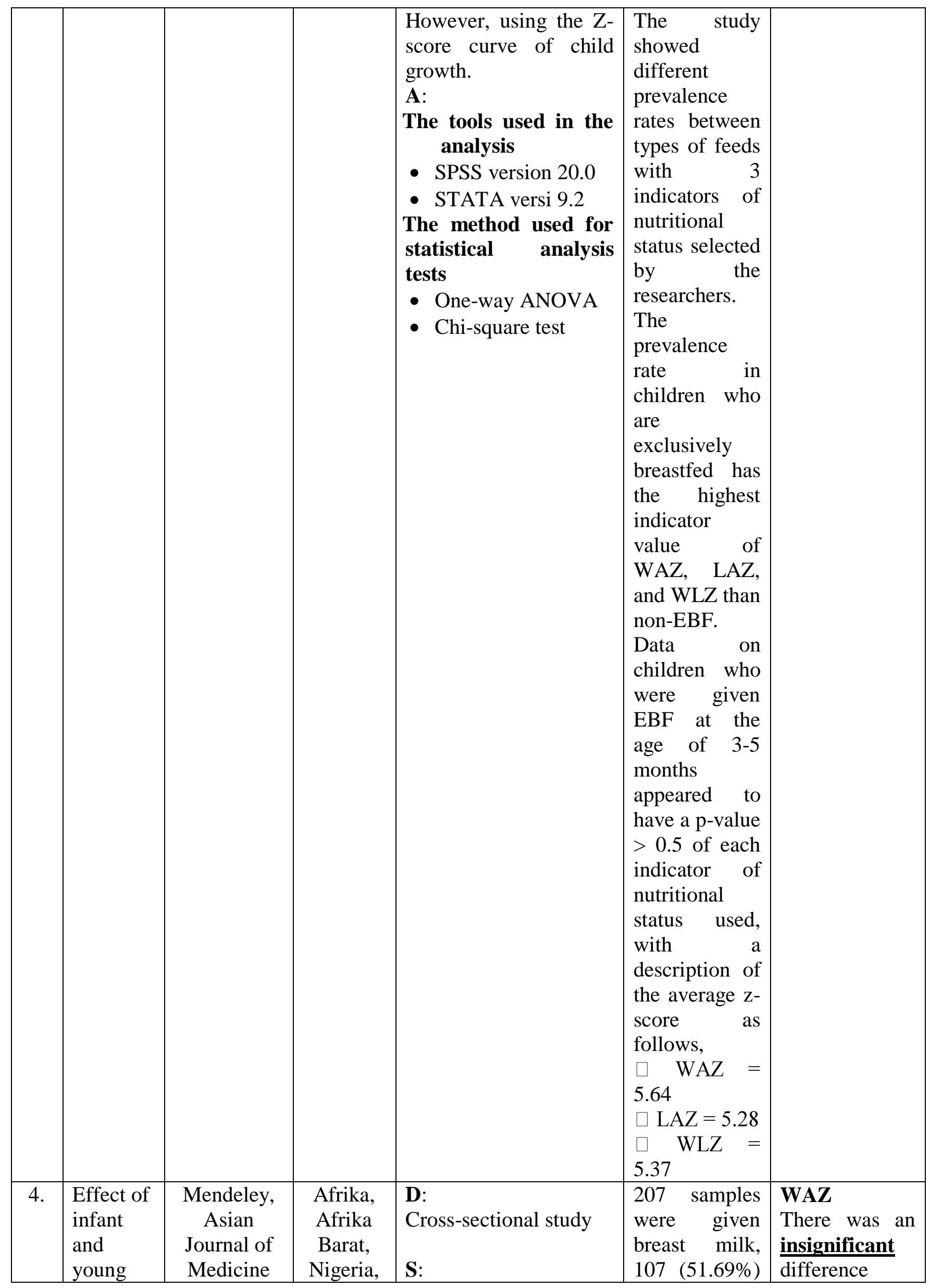




\begin{tabular}{|c|c|c|c|c|c|}
\hline $\begin{array}{l}\text { child } \\
\text { feeding } \\
\text { practices } \\
\text { on the } \\
\text { nutrition } \\
\text { al status } \\
\text { of } \\
\text { children } \\
0-24 \\
\text { months } \\
\text { of age in } \\
\text { Port } \\
\text { Harcourt } \\
\text {, Nigeria } \\
\text { (Tobi \& } \\
\text { George, } \\
\text { 2019) }\end{array}$ & $\begin{array}{c}\text { and Health, } \\
2020,-,-, 1- \\
21\end{array}$ & $\begin{array}{c}\text { Riveres } \\
\text { state }\end{array}$ & 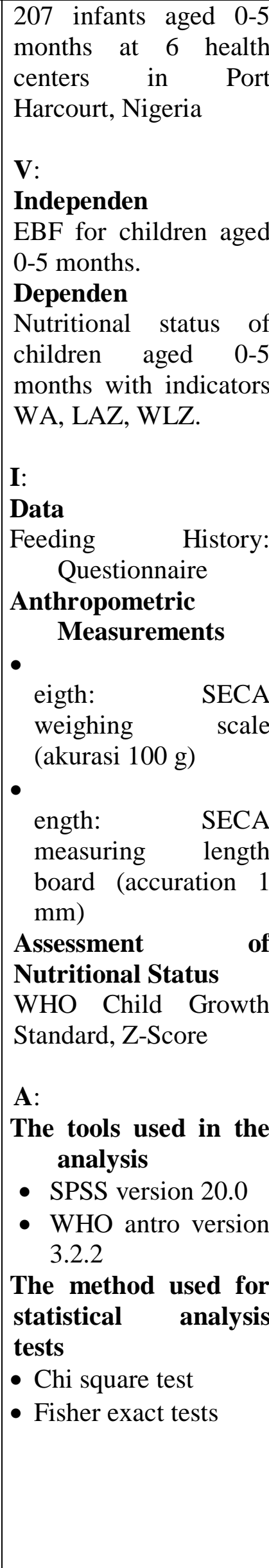 & $\begin{array}{l}\text { of the samples } \\
\text { were given } \\
\text { EBF. } 41 \\
\text { (38.1\%) of } \\
107 \text { samples } \\
\text { were EBF } \\
\text { children until } \\
\text { the age of } 4-5 \\
\text { months The } \\
\text { following is a } \\
\text { description of } \\
\text { the data for } \\
\text { each } \\
\text { indicator, } \\
\text { WAZ } \\
\text { There was an } \\
\text { insignificant } \\
\text { relationship } \\
\text { between } \\
\text { children who } \\
\text { were EBF and } \\
\text { not EBF on } \\
\text { the WAZ } \\
\text { indicator of } \\
\text { nutritional } \\
\text { status, with a } \\
\text { value of P = } \\
0.931 \text { There } \\
\text { were } 106 \\
\text { samples } \\
\text { (53.5\% when } \\
\text { compared to } \\
\text { the normal } \\
\text { category in } \\
\text { the group that } \\
\text { was not EBF) } \\
\text { and } 1 \text { sample } \\
\text { (11.1\% when } \\
\text { compared } \\
\text { with the } \\
\text { normal } \\
\text { category in } \\
\text { the group that } \\
\text { was not EBF) } \\
\text { samples that } \\
\text { fall into the } \\
\text { underweight } \\
\text { category. } \\
\text { LAZ } \\
\text { There was a }\end{array}$ & $\begin{array}{l}\text { between the } \\
\text { type of } \\
\text { breastfeeding } \\
\text { and nutritional } \\
\text { status WAZ } \\
\text { indicator. } \\
\text { LAZ \& WLZ } \\
\text { There was an } \\
\text { significant } \\
\text { difference } \\
\text { between the } \\
\text { type } \\
\text { breastfeeding } \\
\text { and nutritional } \\
\text { status LAZ and } \\
\text { WLZ indicator. }\end{array}$ \\
\hline
\end{tabular}




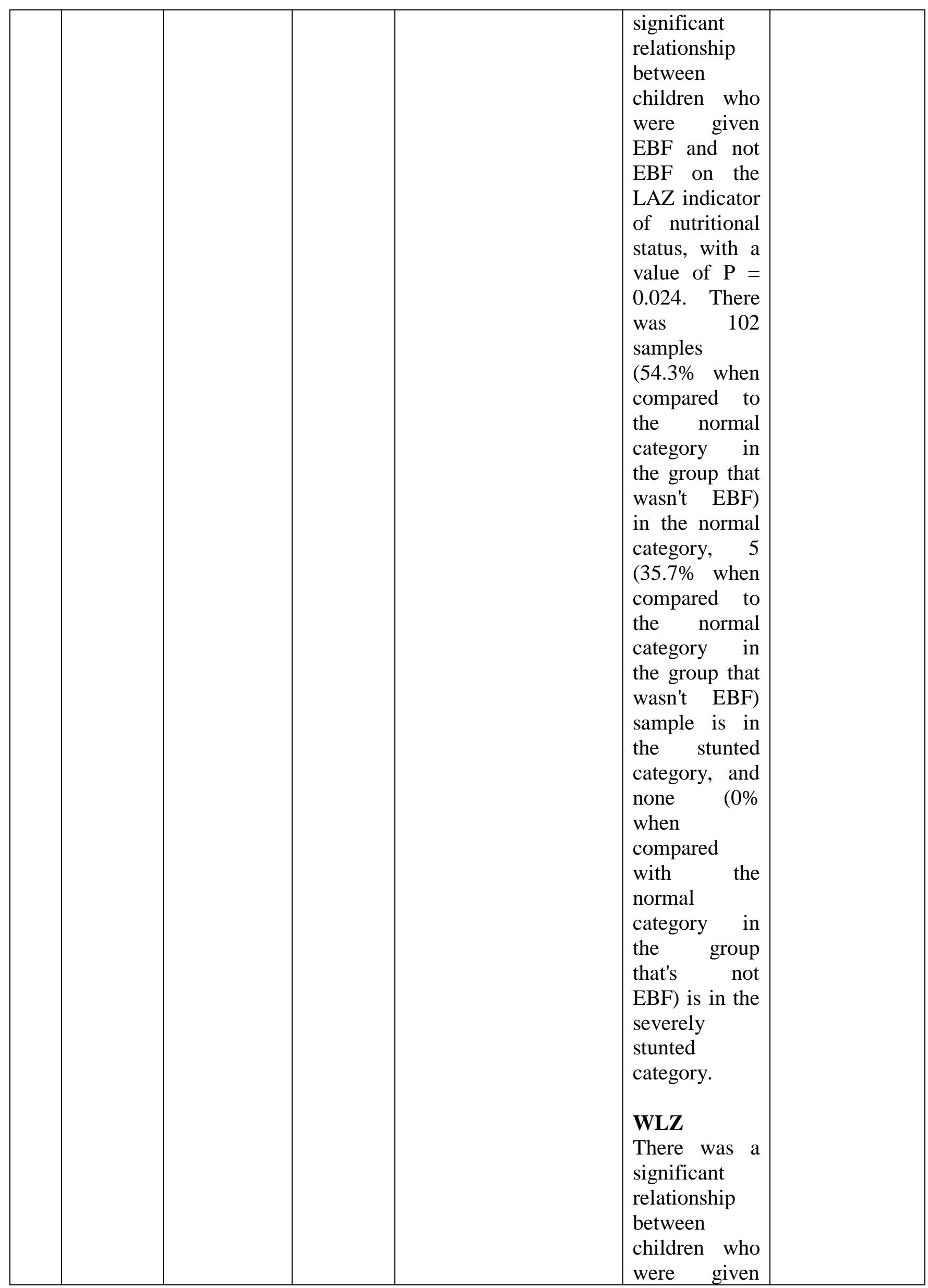




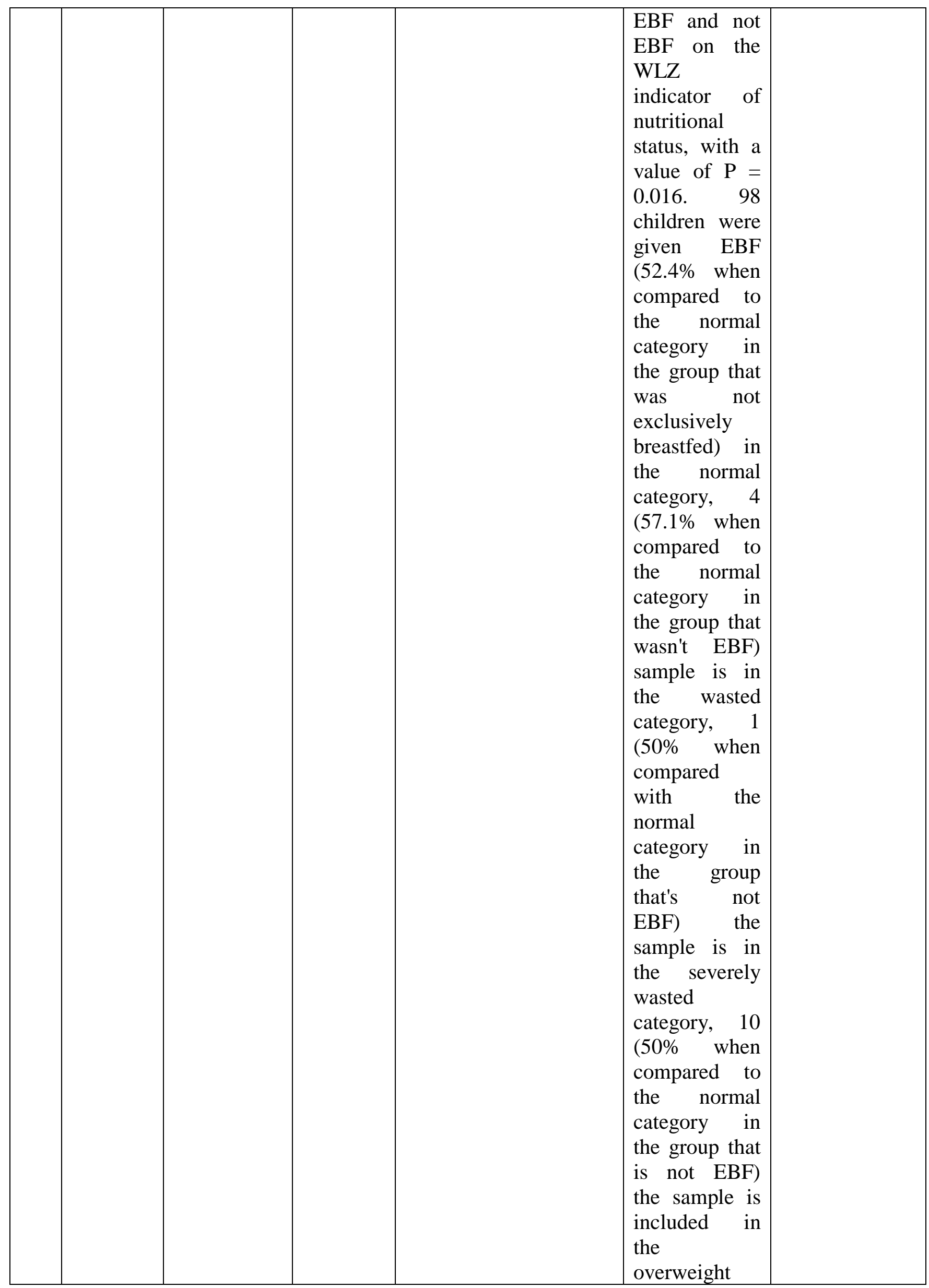




\begin{tabular}{|c|c|c|c|c|c|c|}
\hline & & & & & $\begin{array}{l}\text { category, and } \\
3 \text { (37.5\% } \\
\text { when } \\
\text { compared } \\
\text { with the } \\
\text { normal } \\
\text { category in } \\
\text { the group that } \\
\text { was not EBF) } \\
\text { the sample } \\
\text { was in the } \\
\text { obese } \\
\text { category. }\end{array}$ & \\
\hline 5. & $\begin{array}{c}\text { Randomi } \\
\text { zed } \\
\text { Controlle } \\
\mathrm{d} \text { trial of } \\
4 \\
\text { compare } \\
\mathrm{d} \text { with } 6 \\
\text { mo of } \\
\text { exclusive } \\
\text { breastfee } \\
\text { ding in } \\
\text { Iceland: } \\
\text { differenc } \\
\text { es in } \\
\text { breast- } \\
\text { milk } \\
\text { intake by } \\
\text { stable- } \\
\text { isotope } \\
\text { probe } \\
\text { (Wells et } \\
\text { al., } \\
\text { 2012) }\end{array}$ & $\begin{array}{c}\text { Pubmed, } \\
\text { Am J Clin } \\
\text { Nutr., 2012, } \\
96,1,73-77\end{array}$ & $\begin{array}{l}\text { Europe, } \\
\text { Iceland, } \\
\text { Reykjavi } \\
\text { k }\end{array}$ & 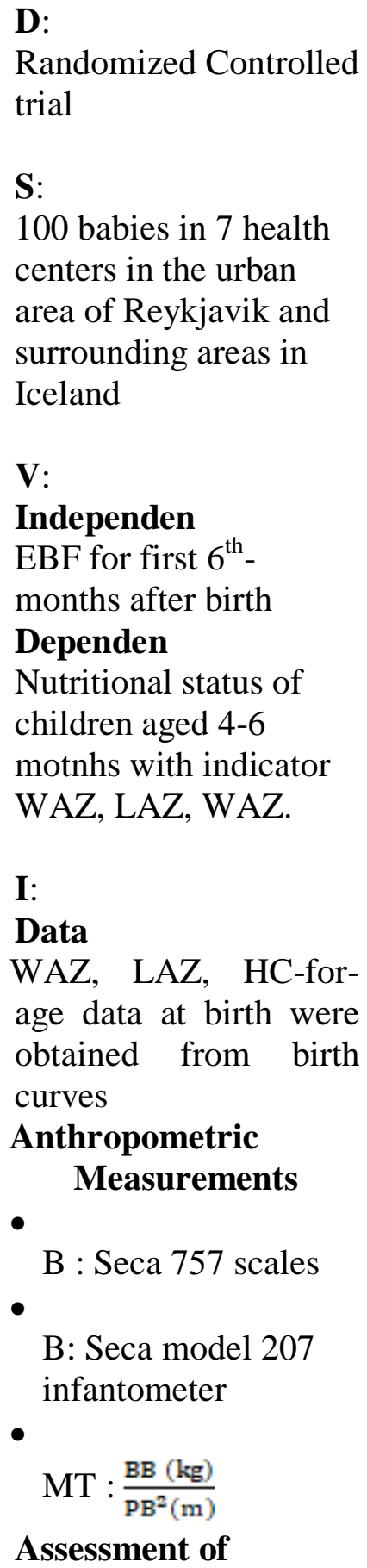 & $\begin{array}{l}50 \text { of the } 100 \\
\text { incoming } \\
\text { samples were } \\
\text { given EBF. } \\
\text { Studies show } \\
\text { that there is a } \\
\text { significant } \\
\text { relationship } \\
\text { from the } \\
\text { WHO rom } \\
\text { recommended } \\
\text { average rate } \\
\text { between } \\
\text { exclusive } \\
\text { breastfeeding } \\
\text { and several } \\
\text { indicators of } \\
\text { nutritional } \\
\text { status such as } \\
\text { WAZ (0.36 } \pm \\
0.99) \text { LAZ } \\
(0.77 \pm 0.84) \text {, } \\
\text { and HC-for- } \\
\text { age (1.02 } \pm \\
0.89) \text { The } \\
\text { BMI-for-age } \\
\text { indicator (- } \\
0.01 \pm 1.04) \\
\text { found an } \\
\text { insignificant } \\
\text { difference. } \\
\text { The results of } \\
\text { this study } \\
\text { show that the } \\
\text { energy intake } \\
\text { and milk } \\
\text { production of } \\
\text { breast }\end{array}$ & $\begin{array}{l}\text { WAZ, LAZ, } \\
\text { HC-for-age } \\
\text { There was a } \\
\text { significant } \\
\frac{\text { result between }}{\text { EBF and }} \\
\text { nutritional } \\
\text { status } \\
\text { BMI-for-age } \\
\text { There was an } \\
\text { insignificant } \\
\text { difference } \\
\text { between the } \\
\text { EBF and } \\
\text { nutritional } \\
\text { status BMI- } \\
\text { for-age } \\
\text { indicator. }\end{array}$ \\
\hline
\end{tabular}




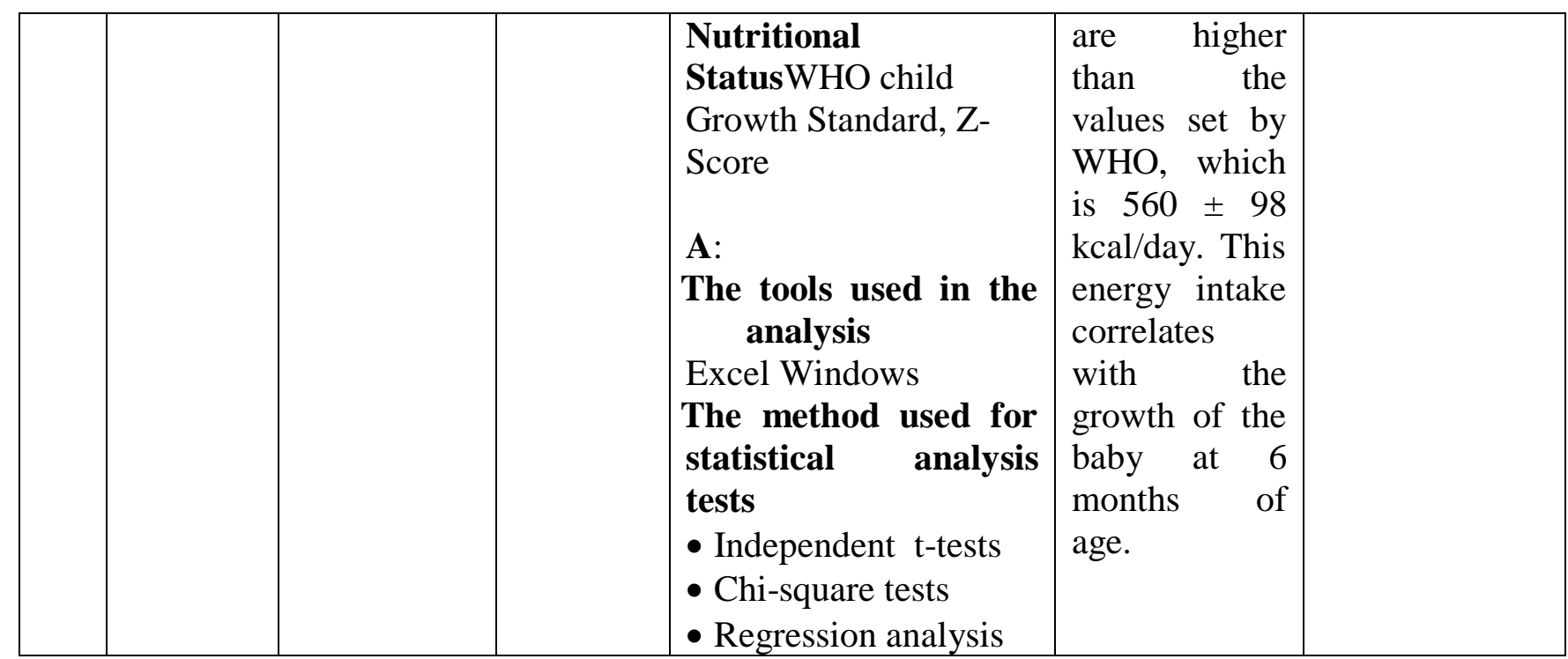

\section{RESULT AND DISCUSSION}

The results of the analysis showed that there was insignificant relationship between $\mathrm{EBF}<$ 6 months with nutritional status of WAZ, LAZ, WLZ, and BMI on age. There is a significant relationship with the HC-for-age indicator.

The first indicator is WAZ. Weight is a composite measurement of the total body. The

weight changes are sensitive and easily visible in a short time, also can describe the current nutritional status. Weight is the result of an increase or decrease in various tissues in the body as bone, muscle, fat, body fluids, etc. (Soetjiningsih \& Ranuh, 2013). This indicator is discussed in four of the literature. Studies by Tobi \& George (2019) and Wells et al. (2012) show significant results. The insignificance result is a study by Bechiri et al. (2020) and Ma et al. (2014).

Tobi \& George (2019) studies were dominated by the normal category for the WAZ indicator. This study was supported by Anderson et al. (2016), who stated that the levels of adiponectin in breast milk maintain the stability of WAZ. Adiponectin levels depend on maternal BMI (Subarjati \& Nuryanto, 2015).

Wells et al. (2012) studies show the same result as Tobi \& George (2019). This study predominantly multiparous mother. According to Bachour, et al. (2012), parity can influence higher lipid levels. Also supported by Anderson et al. (2016) research states that adiponectin levels in human milk can maintain WAZ stability. One sample was in the underweight category. When it happened to EBF children at the age of 0-3 months, it was related. According to Nigatu, Azage, \& Motbainor, (2019), they state that the incidence of underweight can occur because of the breastfeeding termination at the age of 0-3 months. The results of Khan \& Islam (2017) study also showed the same thing, termination of breastfeeding can increase the risk of underweight in children. Two of those statements are also supported by Wells et al. (2012) data, there's only 41 out of 107 samples are EBF at the age of 4-5 months.

Bechiri et al. (2020) don't present nutritional status data for the sample provided by EBF, but state that there is an insignificant relationship. Data are stating the nutritional status of girls $>+1 \mathrm{SD}$ (body-weight excess 
risk). If the child is from the EBF group and has a mother who is overweight, this is related. This is supported by the research of BadilloSuárez et al. (2017), who state that overweight mothers have higher levels of saturated fatty acids and lower concentrations of omega 3 fatty acids than mothers who have a normal BMI. The likelihood that the two children came from the non-EBF group is related if the child is given formula milk. Based on research by Giugliani (2019), that children who receive formula milk have a faster weight gain when compared to children who receive EBF.

Ma et al. (2014) stated that the insignificant relationship in their study occurred due to a lack of intake of macronutrients and micronutrients, especially vitamin A and zinc. Prentice et al. (2016) stated that nutritional status is influenced by human milk composition. Emphasized by Ballard \& Morrow (2013) and Sjarif et al. (2011) stated that the level of vitamin A in breast milk depends on food intake and deposits in the mother's body. Vitamin A and zinc are essential components for optimal growth (Hidayati et al., 2019; WHO, 2019). The need for zinc in children depends on the content in the child's diet. Zinc levels in breast milk also depend on the mother's genetics. Obese mothers also had lower zinc levels. Zinc levels can also depend on pregnant age, birth weight, infant gender, cesarean delivery, preterm delivery, and vitamin D supplementation (Qian, Wang, Tang, Zhang, \& Cai, 2012).

According to Ma et al. (2014) data, the sample with EBF has a higher WAZ than not EBF group. However, this figure does not reach the $\mathrm{p}$-value $<0.05$. The higher WAZ in the EBF sample is supported by Basrowi (2018) theory which states that breast milk contains tropic factors that can support the maturation of gastrointestinal function, to maximize food absorption in the intestine.
Ma et al. (2014) also stated that there is a lack of energy intake in children who are given breast milk. Based on the data that there's a decrease in the amount of energy in breast milk. Fat is the main source of energy in breast milk. The level and composition of fat in breast milk depends on several factors, such as dietary intake and maternal parity. Several studies have shown that $25 \%$ of the variation in fat concentration is derived from protein intake (Ballard \& Morrow, 2013; Lyons, Ryan, Dempsey, Ross, \& Stanton, 2020; Sjarif et al., 2011). This is also reinforced by (Tian et al., 2019) research, his research was conducted in Asia, China. Tian et al. (2019) stated that the mother's diet affects the level of macronutrient intake and the fatty acid profile of milk in breastfeeding women.

The second indicator is LAZ, a linear growth standard that uses a body length basis with children 0-24 months of age. Body length describes the measurement of bone mass growth that occurs as a result of nutritional intake, which is measured in the supine (Par'i, Wiyono, \& Harjatmo, 2017; WHO, 2006). This indicator was discussed in four of the literature. The result of Tobi \& George (2019) and Wells et al. (2012) study show that there are significant results, while the study by Bechiri et al. (2020) and Ma et al. (2014) shows insignificance.

Tobi \& George (2019) study were states that there's a significant result. Study was dominated by the normal category for the LAZ indicator. Ma et al. (2014) study also shows the same stated. Supported by Uwiringiyimana, et al. (2019) stated that EBF prevents short stature.

Bechiri et al. (2020) study were stated that there is an insignificant result. In their study state that there is a $3,5 \%$ stunted sample. If the sample comes from a group of children with $\mathrm{EBF}$, then this state was supported by Lestari 
\& Dwihestie (2020) stated. They stated that EBF for 6th months related to stunted incidence. Contrary to Uwiringiyimana, et al. (2019) which states that EBF can prevent stunted.

Ma et al. (2014) stated that the insignificant relationship in their study occurred due to a lack of intake of macronutrients and micronutrients, especially vitamin A and zinc. Prentice et al. (2016) stated that nutritional status is influenced by human milk composition. Emphasized by Ballard \& Morrow (2013) and Sjarif et al. (2011) stated that the level Vitamin A and zinc are essential components for optimal growth (Hidayati et al., 2019; WHO, 2019). According to Anindya, Salimo, \& Dewi (2020) research, adequate zinc intake in mothers during breastfeeding is significantly associated with reducing the incidence of stunting in children. The need for zinc in children depends on the content in the child's diet. Zinc levels in breast milk also depend on the mother's genetics. Obese mothers also had lower zinc levels. Zinc levels can also depend on pregnant age, birth weight, infant gender, cesarean delivery, preterm delivery, and vitamin D supplementation (Qian et al., 2012).

According to Ma et al. (2014) data, the sample with EBF has a higher LAZ than not EBF group. However, this figure does not reach the $\mathrm{p}$-value $<0.05$. The higher WAZ in the EBF sample is supported by Basrowi (2018) theory which states that breast milk contains tropic factors that can support the maturation of gastrointestinal function, to maximize food absorption in the intestine.

The third indicator is WLZ, a growth standard using body weight for body length in children aged $<2$ years. This indicator index can determine the ratio between total body weight and body length during the growing period (Kemenkes RI, 2020). This indicator was discussed in two of the literature, namely Tobi $\&$ George (2019) and Ma et al. (2014). Two of them showed insignificant results.

Tobi \& George (2019) compared the EBF and non-EBF groups, with results in two categories, normal \& wasting. There are 89 samples that are normal, which results in the WHO recommendation. There were 4 samples of the wasted category and one sample of severely wasted. The first possibility, human milk quality can't meet the baby's needs. The second possibility, EBF termination at 0-3 months (Nigatu et al., 2019). Supported by Tobi \& George (2019), there is a decreasing number of children who are given EBF up to the age of 5 months.

In Tobi \& George (2019) studies, there are 10 samples of the overweight category and 3 samples of the obese category. Tobi \& George (2019) did not include the nutritional status with BMI maternal indicator. BMI maternal > 30 (overweight) could be related to the levels of components of breast milk. This is supported by Badillo-Suárez et al. (2017) research, which states that overweight mothers have higher levels of saturated fatty acids and lower concentrations of omega 3 fatty acids than mothers who have a normal BMI. The second possibility is due to formula feeding, as we know that only 41 out of 107 samples were exclusively breastfed until the age of 4-5 months. This statement is supported by the research of Giugliani (2019), that children who receive formula milk have a faster weight gain when compared to children who receive EBF. Rapid weight gain can put your child at risk of being overweight. Being overweight in children can be an important contributor to adult obesity, diabetes, and non-communicable diseases (Black et al., 2013).

Ma et al. (2014) stated that the insignificant relationship in their study occurred due to a lack of intake of macronutrients and 
micronutrients, especially vitamin A and zinc. Prentice et al. (2016) stated that nutritional status is influenced by human milk composition. Emphasized by Ballard \& Morrow (2013) and Sjarif et al. (2011) stated that the level of vitamin A in breast milk depends on food intake and deposits in the mother's body. Vitamin A and zinc are essential components for optimal growth (Hidayati et al., 2019; WHO, 2019). The need for zinc in children depends on the content in the child's diet. Zinc levels in breast milk also depend on the mother's genetics. Obese mothers also had lower zinc levels. Zinc levels can also depend on pregnant age, birth weight, infant gender, cesarean delivery, preterm delivery, and vitamin D supplementation (Qian et al., 2012).

According to Ma et al. (2014) data, the sample with EBF has a higher WLZ than not EBF group. However, this figure does not reach the $\mathrm{p}$-value $<0.05$. The higher WAZ in the EBF sample is supported by Basrowi (2018) theory which states that breast milk contains tropic factors that can support the maturation of gastrointestinal function, to maximize food absorption in the intestine.

Insignificant relationship with the WLZ indicator in the research of Tobi \& George (2019) with Ma et al. (2014) can also be related to hormone levels in breast milk. These types of hormones are adiponectin, insulin, and leptin. Based on research by Chan et al. (2018), high levels of insulin and leptin are associated with low WLZ indicators in infants. Insulin and leptin levels in breast milk correlate with the mother's BMI, parity, and ethnicity. The research of Chan et al. (2018) also stated that adiponectin doesn't correlate with the WLZ indicator. Contrary to the theory of Watson et al. (2013), they stated that adiponectin is involved in regulating endocrine response. This response regulation affects the regulation of eating and appetite so that it can prevent the incidence of overweight and obesity.

The fourth indicator is BMI-for-age. This indicator is a standard of growth using the Body Mass Index (BMI) standard with age. $\mathrm{BMI}$ is the ratio of body weight $(\mathrm{kg}) /$ supine length $\left(\mathrm{m}^{2}\right)$ (Kemenkes RI, 2020). The BMIfor-age indicator can describe the excessive proportion of fat, but it is unable to distinguish the weight that comes from fat, muscle, and bone (Soetjiningsih \& Ranuh, 2013). BMI-forage indicator was discussed in two of the literature, namely Wells et al. (2012) and Bechiri et al. (2020). Two of them showed insignificant results.

Wells et al. (2012) study showed insignificant results. Their research was supported by the results of Giugliani (2019) study which shown that children who were given EBF had a slower increase in BMI. This happens because in EBF children only an increase in lean mass.

Bechiri et al. (2020) state that $3.1 \%$ of 159 samples are overweight. If this category is in the EBF group, there's a possibility that it's caused by a mother's BMI > 30 (overweight). The studies show that maternal BMI is $28 \pm$ $4.5 \mathrm{~kg} / \mathrm{m}^{2}$ it appears that there are mothers with BMI> 30. Human milk from overweight mothers produces higher levels of saturated fatty acids and lower levels of omega 3 fatty acids. The incidence of overweight in children can also be caused by feeding formula milk (Mäkelä et al.,2013). This statement was also supported by Giugliani (2019), who stated that children who received formula milk had a faster increase in BMI. Rapid weight gain can put your child at risk of being overweight. Being overweight in children can be an important contributor to adult obesity, diabetes, and non-communicable diseases (Black et al., 2013). 
Bechiri et al. (2020) stated that $7.1 \%$ of 159 samples were wasting categorized. If the sample comes from the EBF group, there is a possibility that may be due to EBF termination of children aged 0-3 months (Nigatu et al., 2019). Following the data of Bechiri et al. (2020) there was a decrease in children who were given $\mathrm{EBF}$, from 25 samples in the first month to 12 samples in the fifth month.

The fifth indicator is HC-for-age. This assessment to see the growth in head circumference and brain growth. The HC-forage assessment doesn't correlate with brain volume but is the best predictor of neurodevelopment, global brain growth, and internal structures. This indicator was discussed in two of the literature, namely Anindya dkk. (2019) and Wells et al. (2012). Two of them showed significant results.

Anindya et al. (2019) state that 91 from 128 samples get EBF. This study shows that there are 98 samples in the normal category, while 30 samples have the microcephaly category. On the other hand, the research of Anindya et al. (2019) stating that microcephaly found in 10 samples came from the group of children who were EBF, and 20 samples came from the group of children who were not exclusively breastfed. After compared to the nutritional status of the mother, 27 samples came from mothers with normal nutritional status. Another 3 samples came from abnormal nutritional status. The section on normal maternal nutritional status doesn't explain how the process of breastfeeding and food intake for the mother.

There's a different type of breast milk at the end of the breastfeeding process, called hindmilk. Hindmilk has a higher concentration of fat when compared to foremilk, which makes the baby more full and needed in brain development. It's recommended to breastfeed until the breast is empty (Lyons, Ryan,
Dempsey, Ross, \& Stanton, 2020; Prawirohardjo, 2016; Sjarif et al1., 2011).

Fatty acids variation in breast milk also related to maternal dietary intake, particularly in Long Chain Polyunsaturated Fatty Acids (LCPUFAs), such as omega 6 fatty acids, omega 3 fatty acids, Docosahexaenoic acid (DHA), and AA (Ballard \& Morrow, 2013; Lyons et al., 2020; Sjarif et al., 2011). Other components needed in brain development are choline, taurine, iodine, and iron (Soetjiningsih \& Ranuh, 2013). Choline is a form of vitamin B. Choline levels in breast milk depend on food intake and deposits in the mother's body (Ballard \& Morrow, 2013; Sjarif et al., 2011). Taurine is part of a protein. Taurine has high protein levels in colostrum. Increased protein concentration is influenced by maternal nutritional status, especially the WHZ indicator (Ballard \& Morrow, 2013).

Research by Mello et al. (2019) stated that post-birth microcephaly also occurs due to breastfeeding exposure to the Zika virus. Quoted in the compass, regarding the statement of the Eijkman Institute for Molecular Biology (LBME) that this virus exists in Indonesia, but doesn't spread quickly and in certain people only. This type of virus comes from the same type of mosquito (Aedes) as the dengue virus, that some people already have antibodies to the dengue virus and are immune to the Zika virus (Putra, 2017).

Research by Anindya et al. (2019) also didn't state post-birth HC-for-age indicators. HC-forage is something that is not commonly done to assess post-birth in Indonesia. Generally, microcephaly begins to appear from birth, with the cause is still unclear. In general, the incidence of microcephaly occurs due to genetic changes or exposure from the womb, such as exposure to infections during pregnancy, exposure to chemicals (alcohol, 
drugs, toxic chemicals), the condition of pregnant women with severe malnutrition, as well as obstruction of blood flow to the brain so that it interferes with brain development (CDC, 2020).

Wells et al. (2012) found the same significant relationship between exclusive breastfeeding and the nutritional status of the $\mathrm{HC}$-for-age indicator. HC-for-age of EBF children was higher than HC-for-age of non-EBF children. According to Herba et al. (2013) states that children who get EBF have more optimal brain development and have greater HC. Ferreira et al. (2013) also says the same thing, that EBF $\geq$ 4 months is associated with greater $\mathrm{HC}$.

\section{Suggestion}

Health workers should provide counseling about breastfeeding and nutritional status interventions for mothers-to-be as breast milk producers and givers. The government must make policies that support the health and nutritional status of children, especially during the first 1000 days. The government must also make a policy that ensures better nutritional status for prospective women and mothers so that the quality of the breast milk produced is supporting the fulfillment of children's needs in the first 2 years. Through the services of these two parties, it's hoped to form a better quality of generation and human.

On the other hand, health care providers and government need to form knowledge to the public about the importance of breast milk. Through optimization society and environment, it can support the nutritional status also food supply of mothers. Resulting in a mother produced good quality breast milk that can meet the children's needs.

Recommendations for researchers to conduct further research for finding the cause of the insignificant relationship between exclusive breastfeeding and the nutritional status of full- term Infant in the first 6th-months after birth. There is also a need for more focused and detailed research. A researcher has to divide nutritional status data between EBF children until 5 months old and children who don't EBF until the age of 5 months. Full-term and preterm infant nutritional status have a different calculation in real age, so the nutritional status data have to divide.

\section{REFERENCE}

1000 days. (2020). Why 1000 Days? Retrieved from 1000 days website: https://thousanddays.org/why-1000-days/

Anderson, J., McKinley, K., Onugha, J., Duazo, P., Chernoff, M., \& Quinn, E. A. (2016). Lower levels of human milk adiponectin predict offspring weight for age: a study in a lean population of Filipinos. Maternal and Child Nutrition. https://doi.org/10.1111/mcn.12216

Anindya, I. G., Salimo, H., \& Dewi, Y. R. R. (2019). Hubungan Pemberian ASI Eksklusif Dan Status Gizi Ibu Dengan Pertumbuhan Lingkar Kepala Bayi Usia 6 Bulan Relationship among Exclusive Breastfeeding and Maternal Nutritional Status with the Growth of Head Circumference. 263-268. https://doi.org/10.2473/amnt.v3i4.2019.

Anindya, I. G., Salimo, H., \& Dewi, Y. R. R. (2020). The Association between Exclusive Breastfeeding, Maternal Nutritional Status, Maternal Zinc Intake, and Stunting in Infants Aged 6 Months. Journal of Maternal and Child Health, 5(1), 37-49. Retrieved from https://thejmch.com/index.php?journal=thejmc h\&page $=$ article \&op $=$ view $\&$ path $\% 5 \mathrm{~B} \% 5 \mathrm{D}=32$ 0

Bachour, P., Yafawi, R., Jaber, F., Choueiri, E., \& Abdel-Razzak, Z. (2012). Effects of smoking, mother's age, body mass index, and parity number on lipid, protein, and secretory immunoglobulin a concentrations of human milk. Breastfeeding Medicine. https://doi.org/10.1089/bfm.2011.0038 
Badillo-Suárez, P. A., Rodríguez-Cruz, M., \& Nieves-Morales, X. (2017). Impact of Metabolic Hormones Secreted in Human Breast Milk on Nutritional Programming in Childhood Obesity. Journal of Mammary Gland Biology and Neoplasia, 22(3), 171-191. https://doi.org/10.1007/s10911-017-9382-y

Ballard, O., \& Morrow, A. L. (2013). Human Milk Composition: Nutrients and Bioactive Factors. NIH-PA Author Manuscript, 3(3), 221-233.

https://doi.org/10.1016/j.pcl.2012.10.002.Hum an

Basrowi, R. W. (2018). Perkembangan dan Kematangan Saluran Cerna. (June). Retrieved from https://www.nestlenutritioninstitute.org/docs/default-source/indonesiadocument-library/publications/refa_lactogenhappy-tummy-modul-vol2-

5_isi_bab2_12jun18.pdf?sfvrsn=8e6c42ed_0

Bechiri, L., Kadi, H., Bouldjadj, I., Elokki, E. H. M., Dahliz, I., \& Dahel, C. C. (2020). Breastfeeding and growth of healthy infants followed from birth to 18 months. African Journal of Food, Agriculture, Nutrition and Development, 20(5), 16386-16402. https://doi.org/10.18697/AJFAND.93.19250

Black, R. E., Victora, C. G., Walker, S. P., Bhutta, Z. A., Christian, P., De Onis, M., ... Uauy, R. (2013). Maternal and child undernutrition and overweight in low-income and middle-income countries. The Lancet. https://doi.org/10.1016/S0140-6736(13)60937$\mathrm{X}$

Chan, D., Goruk, S., Becker, A. B., Subbarao, P., Mandhane, P. J., Turvey, S. E., ... Azad, M. B. (2018). Adiponectin, leptin and insulin in breast milk: Associations with maternal characteristics and infant body composition in the first year of life. International Journal of Obesity. https://doi.org/10.1038/ijo.2017.189

Ferreira, H. D. S., Xavier Júnior, A. F. S., De Assunção, M. L., Dos Santos, E. A., \& Horta, B. L. (2013). Effect of breastfeeding on head circumference of children from impoverished communities. Breastfeeding Medicine. https://doi.org/10.1089/bfm.2012.0105
Giugliani, E. R. J. (2019). Growth in exclusively breastfed infants. Jornal de Pediatria.

https://doi.org/10.1016/j.jped.2018.11.007

Herba, C. M., Roza, S., Govaert, P., Hofman, A., Jaddoe, V., Verhulst, F. C., \& Tiemeier, H. (2013). Breastfeeding and early brain development: The Generation $\mathrm{R}$ study. Maternal and Child Nutrition. https://doi.org/10.1111/mcn.12015

Hidayati, M. N., Rukmi, R., Perdani, W., Karima, N., Kedokteran, F., Lampung, U., ... Lampung, U. (2019). Peran Zink terhadap Pertumbuhan Anak The Role of Zinc in Children Growth. 8, 168-171.

Kemenkes RI. (2020). Peraturan Menteri Kesehatan Republik Indonesia Nomor 2 Tahun 2020 tentang Standar Antropometri Anak. 143. Retrieved from http://hukor.kemkes.go.id/uploads/produk_huk um/PMK_No_2_Th_2020_ttg_Standar_Antr opometri_Anak.pdf

Khan, M. N., \& Islam, M. M. (2017). Effect of exclusive breastfeeding on selected adverse health and nutritional outcomes: A nationally representative study. BMC Public Health. https://doi.org/10.1186/s12889-017-4913-4

Lestari, E. F., \& Dwihestie, L. K. (2020). ASI Eksklusif Berhubungan dengan Kejadian Stunting pada Balita. Jurnal Ilmiah Permas: Jurnal Ilmiah STIKES Kendal.

Lyons, K. E., Ryan, C. A., Dempsey, E. M., Ross, R. P., \& Stanton, C. (2020). Breast milk, a source of beneficial microbes and associated benefits for infant health. Nutrients, 12(4), 130. https://doi.org/10.3390/nu12041039

Ma, D., Ning, Y., Gao, H., Li, W., Wang, J., Zheng, Y., ... Wang, P. (2014). Nutritional status of breast-fed and non-exclusively breast-fed infants from birth to age 5 months in 8 Chinese cities. Asia Pacific Journal of Clinical Nutrition, 23(2), 282-292. https://doi.org/10.6133/apjcn.2014.23.2.16

Nigatu, D., Azage, M., \& Motbainor, A. (2019). Effect of exclusive breastfeeding 
cessation time on childhood morbidity and adverse nutritional outcomes in Ethiopia: Analysis of the demographic and health surveys. PLoS ONE. https://doi.org/10.1371/journal.pone.0223379

Par'i, H. M., Wiyono, S., \& Harjatmo, T. P. (2017). Bahan Ajar Gizi : Penilaian Status Gizi (Tahun 2017). Retrieved from http://bppsdmk.kemkes.go.id/pusdiksdmk/wpcontent/uploads/2017/11/PENILAIANSTATUS-GIZI-FINAL-SC.pdf

Prawirohardjo, S. (2016). Ilmu Kebidanan Sarwono Prawirohardjo. Edisi Ke-4. Jakarta: Yayasan Bina Pustaka Sarwono Prawirohardjo.

Prentice, P., Ong, K. K., Schoemaker, M. H., Van Tol, E. A. F., Vervoort, J., Hughes, I. A., ... Dunger, D. B. (2016). Breast milk nutrient content and infancy growth. Acta Paediatrica, International Journal of Paediatrics. https://doi.org/10.1111/apa.13362

Qian, L., Wang, B., Tang, N., Zhang, W., \& Cai, W. (2012). Polymorphisms of SLC30A2 and selected perinatal factors associated with low milk zinc in Chinese breastfeeding women. Early Human Development. https://doi.org/10.1016/j.earlhumdev.2012.01. 011

Sjarif, D. R., Lestari, E. D., Mexitalia, M., Nasar, S. S., \& IDAI. (2011). Buku Ajar Nutrisi Pediatrik dan Penyakit Metabolik Jilid 1. Jakarta: Ikatan Dokter Anak Indonesia.

Skirgaudas, P. S. (1987). Pediatric Nutrition Handbook. In The Nurse Practitioner (Vol. 12). https://doi.org/10.1097/00006205198702000-00019

Soetjiningsih, \& Ranuh, I. N. G. (2013). Tumbuh Kembang Anak (2nd ed.). Jakarta: EGC.

Subarjati, A., \& Nuryanto, N. (2015). HUBUNGAN INDEKS MASSA TUBUH DENGAN KADAR LEPTIN DAN ADIPONEKTIN. Journal of Nutrition College. https://doi.org/10.14710/jnc.v4i4.10121
Tian, H. M., Wu, Y. X., Lin, Y. Q., Chen, X. Y., Yu, M., Lu, T., \& Xie, L. (2019). Dietary patterns affect maternal macronutrient intake levels and the fatty acid profile of breast milk in lactating Chinese mothers. Nutrition. https://doi.org/10.1016/j.nut.2018.06.009

Tobi, N. S., \& George, I. O. (2019). Effect of Infant and Young Child Feeding Practices on the Nutritional Status of Children 0-24 Months of Age in Port Harcourt , Nigeria. 17(December 2016), 1-21. https://doi.org/10.9734/AJMAH/2019/v17i430 170

Uwiringiyimana, V., Ocké, M. C., Amer, S., \& Veldkamp, A. (2019). Predictors of stunting with particular focus on complementary feeding practices: A cross-sectional study in the northern province of Rwanda. Nutrition, 60 , 11-18. https://doi.org/10.1016/j.nut.2018.07.016

Watson, R. R., Grimble, G., Preedy, V. R., \& Zibadi, S. (2013). Nutrition in Infancy. In R. R. Watson, G. Grimble, V. R. Preedy, \& S. Zibadi (Eds.), Spingerlink (1st ed., Vol. 53). https://doi.org/10.1007/978-1-62703-224-7

Wells, J. C. K., Jonsdottir, O. H., Hibberd, P. L., Fewtrell, M. S., Thorsdottir, I., Eaton, S., ... Kleinman, R. E. (2012). Randomized controlled trial of 4 compared with 6 mo of exclusive breastfeeding in Iceland: Differences in breast-milk intake by stable-isotope probe. American Journal of Clinical Nutrition, 96(1), 73-79.

https://doi.org/10.3945/ajcn.111.030403

WHO. (2001). The World Health Organization's infant feeding recommendation. Retrieved from World Health Organization website: https://www.who.int/nutrition/topics/infantfee ding_recommendation/en/\#: :text=\%22Exclus ive breastfeeding $\% 22$ is defined as,vitamins $\% 2 \mathrm{C}$ minerals and medicines).

WHO. (2006). WHO child growth standards : length/height-for-age, weight-for-age, weightfor-length, weight-forheight and body mass index-for-age : methods and development. In Developmental Medicine \& Child Neurology 
(Vol. 51). https://doi.org/10.1111/j.14698749.2009.03503.x

WHO. (2019). Vitamin A supplementation in infants and children 6-59 months of age. Retrieved from WHO website: https://www.who.int/elena/titles/vitamina_chil dren/en/. 